\title{
Software Piracy in Chilean e-Society
}

\author{
Ranjan B. Kini \\ MIS, Indiana University Northwest, USA,
}

\begin{abstract}
The Business Software Alliance and their counterparts in the global market are determined to make significant progress in curbing the Software Piracy globally. Their aggressive pursuit in their endeavor has produced results in bringing down the piracy rate. However, despite the highly net-ready Chile being part of the Latin American region still leads in the software piracy rate. In this study, a micro-level research is performed on the convenient sample of Chilean graduate students to measure their moral intensity towards piracy. The results show that Chileans are at the lower level of moral intensity toward Software Piracy. This suggests that more work needs to be done in educating Chileans in curbing the software piracy and its impact on the economy and business environment.
\end{abstract}

\section{Introduction}

As the stage for transforming the current society into an e-Society is gradually built, a challenge that will continue to exacerbate e-Citizens as well as companies will be the continued piracy of digital goods. Digital Piracy is a challenge that both the software industry and the digital content industry continue to face until there is global understanding and value recognition of intellectual property. In educating the e-citizens, the industries involved in producing such products have 
been aggressive in the recent years to introduce some traditional and innovative techniques. For example, Business Software Alliance (a software industry alliance formed to curb the piracy), has been going around the globe establishing local presence to influence national laws and policies in curbing any form of piracy. Using the carrot and stick approach BSA has been trying to be effective for the last decade. The reports published by various global institutions have documented that digital piracy is rather declining at a very small rate in different countries. However, there is also a sense that dollar value of the piracy cost has remained high. Thus, curbing the digital piracy is still clearly an important objective to organizations such as BSA along with other organizations belonging to Alliance for Digital Progress. [2]

Among the organizations forming the coalition to stop the digital piracy, BSA has been the most aggressive organization. BSA, a coalition of software companies is the leading organization in targeting companies and individuals pirating software. Pirating software has been a common phenomenon for the last two decades. However, as the growth in the technology adoption and the diffusion of such technology around globe progresses there have been increases in the software piracy. According to BSA's Global Piracy Study in 2006, although efforts by BSA contributed in the reduction of piracy rate in the annual numbers, because of the growth in PC adoption in the developing countries, the overall average piracy rate remained the same at 35 percent. The report also indicates that the dollar value of piracy, in fact, increased in 2006 by 15 percent or 5 billion US Dollars. The piracy rate ranged from 21 percent in the US to 95 percent in Armenia. [6] The study estimates that in 2006 for every 2USD worth of software purchased legally there was 1USD worth of software bought illegally. Furthermore, the study estimates that for about the half the countries (of total 102) they studied for every 1USD spent on software legally, about 2USD was spent to acquire illegally. The study reports that situation with countries with high piracy rate is ever worse. [6] The study makes a projection that in the next four years global software piracy may reach 180 billion USD.

The BSA study reports based on their four annual studies that variation in piracy rate in different regions is influenced by factor such as "... the strength of intellectual property protection, the availability of pirated software, and cultural differences". The study also reports the piracy rates within the countries are affected by characteristics such as industry, demographics, type of software (system or application), and size 
(SMB) of businesses. The BSA study recommends that countries can use the following five steps to curb the piracy; shifting public attitude towards software piracy by education and awareness, adopting and enforcing World Intellectual Property Organization laws, creating strong and workable enforcement mechanisms, supporting the enforcement mechanisms through dedicated resources, and the country governments leading antipiracy efforts within their own governments. [6]

In the digital age, the opportunities for the piracy to worsen are high. Software piracy, a small sub set of digital piracy alone is expected to be nearly 50 billion USD per year by 2010. [6] The concern for to curb such phenomenon has motivated many academic research studies both at the macro level and micro level. At the macro level, studies have been conducted to identify the influence of cultural factors, legal environment, corporate environment, and ICT maturity level of the country. $[4][5][9][14][17][18][19]$. While, the micro level studies have focused more on influence of demographic factors, ethical models, moral intensity and individual behavior, etc. Both macro level and micro-level studies have contributed to the academic as well as practitioner world in identifying and understanding factors to focus when deploying resources to curb software piracy locally as well as nationally. In this study, author's motivation is to study the perception of software piracy and to measure the moral intensity among the citizens of the leading ICT ready country in Latin America, Chile. [7][11][12][14][16]

\section{Literature}

Chile is acknowledged as the most wired or the most e-Ready country in Latin America, according to the 2006 Economist Intelligence Unit Rankings. It is ranked higher than many European Countries in its Network Readiness in 2006 according to World Economic Forum Report. [8] Chile is also commended by many global economic watch groups for their action in advancing the country towards ICT readiness. Chileans through public and private partnership are determined in becoming a leader in ICT use in Latin America. In establishing its robust digital agenda, Chile has established many initiatives focusing on Access, Digital literacy, e-Government, e-transactions (eBusiness), and Legal framework. Digital literacy or human resource development is what the government coordinator for ICT considers as 
the biggest challenge. Chile has recognized ICT as an important instrument to gain economic growth and maturity. In establishing these goals, Chile has recognized that it needs to get itself ready in the transformation process from being a resource-based economy to a knowledge-based economy. [3][10]

Currently, there is limited research available on digital piracy or software piracy in Chile. From the above discussion, it is clear that intensity and pervasiveness of software piracy is highly correlated with ICT maturity, economic development, and cultural understanding of intellectual property and related issues. Chile, considered one of the most developed countries in Latin America, according to BSA is having 68 percent piracy rate while it indicates Latin American region has second highest average in software piracy rate of 66 percent. Chile is indicated to have higher piracy than Columbia, Brazil, and Equador. [6] This is in contrast to many of the local Chilean Spanish newspapers indicating that Chile was having 68 percent in 1994 but because of the government efforts, it fell to 56 in 1997, 59 in 1999, 53 in 2000, and 51 in 2005. According to various articles in newspapers, Chileans pirate software from all socio-economic groups and all sizes of businesses. Some articles mentioned large companies had 35 percent piracy rate while small and medium sized companies had piracy rate of 80 percent. Chilean Asociacion Chilena De Distribuidores De Software A. G. $(A D S)$, the Chilean Software Distribution Association has been actively working with Chilean government to educate citizens about piracy, assess the impact of piracy on tax revenues, impact on labor market, ability to attract foreign investments, etc. Despite the fact that most software can be bought from Mercado Persa (illegal market) at a very low price relative to legal price, ADS believes that it is primarily cultural factors that drive Chileans and businesses to pirate. In 2000, Chilean government estimated over 50 million USD of tax revenues were lost annually because of piracy, and in 2007 it estimates losing 163 million USD of tax revenues. Both the Chilean government and ADS have proposed voluntary certification and audits for companies. ADS hopes to have 5000 companies audited and self-regulate themselves. It had only 400 companies certified in 2005. [1]

In this study, as mentioned above, the author's intent is to measure the moral intensity towards software piracy among Chileans. According to ADS, cultural factors drive most Chileans to pirate the software. Thus, the study attempts to contribute in understanding the perception of 
Chileans regarding pervasiveness of software piracy and contributes in assessing the moral intensity of subjects towards software piracy. [1]

For this research the term Software Piracy, uses the commonly used definition making unauthorized copies of software by individuals or businesses for resale or to use in workplace, school, or home; and, Softlifting uses the definition as illegal copying of software by individuals for personal use but not for resale as in software piracy. Based on the prior research and studies [12] the questionnaire useful in measuring moral intensity towards software piracy in other studies is used in this study. [12]

\section{Research}

In attempting to measure the moral intensity and community effects, authors developed a survey questionnaire that included 11 demographic related questions and 40 Softlifting related questions, as shown in $\mathrm{Ap}$ pendix $A$. In this exploratory study, authors used a convenient sample of MBA students from a leading private university in Santiago, Chile. This survey was first translated in to Spanish and reverse translated for accuracy. The questionnaire was then administered to a small group of students to pretest the questionnaire and correct interpretation. All of these students are fulltime working students. The data was collected between January and May 2005. This is a captive crowd; hence, a little bias is expected. Although this is not a good representative sample of Chilean population, this however is a sample of educated population with a tendency to have highest number in levels of income and highest level of ICT adoption rate. All students were informed that participation was voluntary and that individual student responses will remain completely anonymous. The students were asked to rate the question items on Likert scale to 1 to 5,1 being Strongly disagree and 5 being Strongly agree. It should be pointed out the items I43, I44 and I49 are reverse coded and interpreted appropriately. The authors collected 185 valid responses from the university students. The analysis and findings based on responses to 20 items of the total 49 items specifically related to the students or subjects are discussed in the following sections. 


\section{Findings}

The focus of this study is to capture the perception of students who may be at different levels of Kohlberg's moral stages of development. (Appendix B) Although there were 41 questions, in this study the analysis is performed on responses to the relevant 20 questions. The findings discussed below are based on 183 responses.

The intensity of moral development depends on the way individual rationalizes the decision. In the earlier research, it has been identified that often the moral stage of development of an individual can be transient and situation dependent. Accordingly, there has been some research that indicates that Software Piracy is one such situation. That is, in case of Software Piracy an individual can drop in the level of stage of moral development. [10][11][12]

From Table 1, one can depict a typical respondent in this study as 3140 years old, male, graduate student, has extensive experience with computer, holds a managerial position, and uses software mostly on the job. (Table 1) The Table 2 shows average scores for each of the items. The response to the item V55 with a mean estimate of 8711 copies (for 100 legal copies of software) seems irrational even for students, especially when reports indicate that there are 68 copies for every 100 copies. This perception can distort the true understanding of the situation by the respondent. The distortion may be reflected in their responses to I13 and I12 with high means. With respondents scoring means below 3 for I48, I47 and I36 they have shown that they are above the Level 1 of moral development although slipped below by scoring higher for I12 and I13. With low mean scores for I43, I49 and I44 (reverse scored items) respondents show that they are aware of the consequences but their level of moral development relating to software piracy drives them to be adventurous and drop to Stage 2 as evidenced by I12 and I13 scores.

The correlation Table 3 without any surprises indicates that respondents are consistent in their moral development. The highly significant and high correlations among items representing different levels and stages clearly indicate these respondents do possess a low level of moral intensity towards software piracy. These findings are preliminary. The data will need to be further analyzed with more robust statistical techniques to gain more insights. 


\section{Comments}

The perception of Chileans is that Software Piracy is not a major issue. Everyone is doing it and in general, it is all right to do it is common theme. The responses analyzed in this study are from an educated and higher socio-economic class population. The preliminary evidence from this study suggests that more needs to be performed in terms of educating the public in informing about the Intellectual property and benefits thereof to the economic development, government, labor market and foreign investment.

The level of moral development of individuals is influenced by various factors. Thus, although one should commend Chile for being the technology leader in Latin America, it needs to use appropriate nationwide approach in raising the moral intensity towards Software Piracy (and Digital Piracy), so there will be more rapid reduction of the piracy rate while it continues to be technology leader. 


\section{References}

1. ADS (2008) http://www.ads.cl/

2. Alliance, (2008) http://www.alliancefordigitalprogress.org/content/?p=CoalitionMembers

3. Álvarez, C. (2005) "ICT as a part of Chile's Strategy for Development: Present Issues and Challenges", DIGITAL AGENDA, Deputy Minister of Economy, Government Coordinator for ICT, CHILE.

4. Banerjee, D. (2003) Software Piracy: a Strategic Analysis and Policy Instruments, International Journal of Industrial Organization 21 (1) 97-127.

5. Banerjee, D., Khalid, A.M. and Sturm, J. (2005) Social-economic Development and Software Piracy: an Empirical Assessment, Applied Economics 37, 2091-2097.

6. Business Software Alliance (2007) 2006 Piracy Study. http://w3.bsa.org/globalstudy//upload/2007-Global-Piracy-Study-EN.pdf

7. Cronan, T.P., Foltz, C.B., and Jones, T.W. (2006) Piracy, Computer Crime, and IS Misuse at the University Communications of the ACM 49 (6) 84-90.

8. Dutta, S., Lanvin B., and Paula F. (2005) Global Information Technology Report 2004-2005, World Economic Forum.

9. Husted, B.W. (2000) The Impact of National Culture on Software Piracy Journal of Business Ethics 26(3) 197-211.

10.Kini, R. B. (2007) Vendor Availability: A Key Factor for Outsourcing in Chilean ICT Sector, Information Management \& Computer Security.

11.Kini, R. B., Ramakrishna, H. V., and Vijayraman, B. S. (2004) Shaping of Moral Intensity Regarding Software Piracy: A Comparison Between Thailand and U.S. Students, Journal of Business Ethics.

12.Kini, R. B., Rominger A. R., and Vijayraman, B. S. (2000) An Empirical Study of Software Piracy and Moral Intensity Among University Students, Journal of Computer Information Systems $\operatorname{XXXX(3)~62-72.~}$

13.Kohlberg, L. "Stage and sequence: The Cognitive Developmental Approach to Socialization", in Handbook of Socialization Theory \& Research, D. Growling (ed.), Rand McNally, 1969.

14.Leonard, L.N.K., Cronan, T.P. and Kreie, J. (2004) What Influences IT Ethical Behaviour Intentions--Planned Behaviour, Reasoned Action, Perceived Importance, or Individual Characteristics? Information \& Management 42 (1) 143-158.

15.Marron, D.B. and Steel, D.G. (2000) Which Countries Protect Intellectual Property? The Case of Software Piracy, Economic Inquiry 38(2) 159-174.

16.Peace, A.G., Galletta, D.F. and Thong, J.Y.L. (2003) Software Piracy in the Workplace: A Model and Empirical Test Journal of Management Information Systems 20 (1) 153-177.

17.Ronkainen, I.A. and Guerrero-Cusumano, J.-L. (2001) Correlates of Intellectual Property Violation Multinational Business Review 9(1) 59-65.

18.Shore, B., Venkatachalam, A.R., Solorzano, E., Burn, J.M., Hassan, S.Z. and Janczewski, L.J. (2001) Softlifting and Piracy: Behaviour across Cultures Technology in Society 23 (4) 563-581.

19.Yang, D. and Sonmez, M. (2007) Economic and Cultural Impact on Intellectual Property Violations: A Study of Software Piracy Journal of World Trade 41 (4) 731-750. 
Table - 1: Demographic Data

\begin{tabular}{|c|c|c|}
\hline Variable & Categories & Number \\
\hline \multirow{6}{*}{ Age Group } & Under 19 & 0 \\
\hline & $19-21$ & 1 \\
\hline & $22-25$ & 7 \\
\hline & $26-30$ & 42 \\
\hline & $31-40$ & 96 \\
\hline & Over 40 & 25 \\
\hline \multirow{2}{*}{ Gender } & Male & 119 \\
\hline & Female & 52 \\
\hline \multirow{2}{*}{ Program } & Graduate & 144 \\
\hline & Undergraduate & 26 \\
\hline Computer & Has at Home & 162 \\
\hline \multirow{4}{*}{$\begin{array}{l}\text { Computing Experi- } \\
\text { ence }\end{array}$} & None & 2 \\
\hline & Basic & 28 \\
\hline & Extensive & 113 \\
\hline & Advanced & 28 \\
\hline \multirow{4}{*}{$\begin{array}{l}\text { Current Employ- } \\
\text { ment }\end{array}$} & Clerical & 0 \\
\hline & Supervisory & 25 \\
\hline & Managerial & 81 \\
\hline & Professional & 55 \\
\hline \multirow{4}{*}{ Using Software for } & On the job & 140 \\
\hline & Classroom use & 6 \\
\hline & Personal use & 23 \\
\hline & Advanced & 0 \\
\hline
\end{tabular}




\begin{tabular}{|c|c|c|c|c|c|c|}
\hline \multicolumn{7}{|c|}{ Table 2: Descriptive Statistics } \\
\hline & $\mathrm{N}$ & Min. & Max. & Mean & Std. Dev & \\
\hline V55 & 169 & 0 & 1000000 & 8711 & 77586 & $\begin{array}{l}\text { I think for every } 100 \text { legal copies of software in } \\
\text { the market there are at least } \\
\text { es made of the same software in Chile. }\end{array}$ \\
\hline $\mathrm{I} 13$ & 183 & 1 & 5 & 4.251 & 0.840 & $\begin{array}{l}\text { I believe most students copy commercial } \\
\text { software instead of buying it. }\end{array}$ \\
\hline $\mathrm{I} 28$ & 183 & 1 & 5 & 3.934 & 0.929 & $\begin{array}{l}\text { I think it is alright for } a \text { student to use a univer- } \\
\text { sity owned software at home to complete uni- } \\
\text { versity assignments. }\end{array}$ \\
\hline $\mathrm{I} 12$ & 183 & 1 & 5 & 3.820 & 1.019 & $\begin{array}{l}\text { I believe most people copy commercial soft- } \\
\text { ware instead of buying it. }\end{array}$ \\
\hline I34 & 184 & 1 & 5 & 3.625 & 1.048 & $\begin{array}{l}\text { I think it is alright for a student to use univer- } \\
\text { sity computer and software for their benefits as } \\
\text { long as it has no adverse effect on others. }\end{array}$ \\
\hline $\mathrm{I} 22$ & 184 & 1 & 5 & 3.462 & 1.086 & $\begin{array}{l}\text { I think it is alright for } a \text { student to use univer- } \\
\text { sity computers and software for their social or- } \\
\text { ganizations. }\end{array}$ \\
\hline I46 & 183 & 1 & 5 & 3.328 & 1.049 & $\begin{array}{l}\text { I think it is alright for me to "try out" software } \\
\text { so long as I intend to buy it in the future. }\end{array}$ \\
\hline $\mathrm{I} 25$ & 183 & 1 & 5 & 3.306 & 1.215 & $\begin{array}{l}\text { I think it is all right for } a \text { student to copy com- } \\
\text { mercial software to evaluate it for possible pur- } \\
\text { chase. }\end{array}$ \\
\hline I19 & 184 & 1 & 5 & 3.228 & 1.211 & $\begin{array}{l}\text { I think is alright for } a \text { student to use university } \\
\text { computers and software for non-university ac- } \\
\text { tivities. }\end{array}$ \\
\hline I45 & 184 & 1 & 5 & 3.114 & 1.175 & $\begin{array}{l}\text { I think it alright for me to use copied soft- } \\
\text { ware if I would not buy it in any case. }\end{array}$ \\
\hline I31 & 184 & 1 & 5 & 3.098 & 1.141 & $\begin{array}{l}\text { I think it is alright for a student to use a univer- } \\
\text { sity owned software at home for personal use. }\end{array}$ \\
\hline $\mathrm{I} 35$ & 181 & 1 & 5 & 3.077 & 1.142 & $\begin{array}{l}\text { I think it is alright for } a \text { student to use univer- } \\
\text { sity computer and software for their benefits as } \\
\text { long as it has only minor adverse effect on oth- } \\
\text { ers. }\end{array}$ \\
\hline I16 & 184 & 1 & 5 & 3.011 & 1.145 & $\begin{array}{l}\text { I think it is alright for a student to copy } \\
\text { commercial software instead of buying it. }\end{array}$ \\
\hline I48 & 184 & 1 & 5 & 2.516 & 1.106 & $\begin{array}{l}\text { I think it is alright for me to copy commercial } \\
\text { software because it is unlikely that I will be } \\
\text { caught }\end{array}$ \\
\hline I47 & 183 & 1 & 5 & 2.503 & 1.084 & $\begin{array}{l}\text { I think it is alright for me to copy commercial } \\
\text { software if most people do it. }\end{array}$ \\
\hline I36 & 184 & 1 & 5 & 2.495 & 1.197 & $\begin{array}{l}\text { I think it is alright for } a \text { student to use univer- } \\
\text { sity computer and software for their benefits } \\
\text { regardless of its effect on others. }\end{array}$ \\
\hline I43R & 184 & 0 & 4 & 1.620 & 1.249 & $\begin{array}{l}\text { I think it is illegal for a student to copy com- } \\
\text { mercial software instead of buying it. }\end{array}$ \\
\hline I49R & 184 & 0 & 5 & 1.348 & 1.232 & $\begin{array}{l}\text { I do not think it is right to copy commercial } \\
\text { software. }\end{array}$ \\
\hline I44R & 184 & 0 & 4 & 1.310 & 1.209 & $\begin{array}{l}\text { I think it is illegal for anybody to copy com- } \\
\text { mercial software instead of buying it. }\end{array}$ \\
\hline \multicolumn{3}{|c|}{ Strongly Disagree } & \multicolumn{4}{|c|}{$\mathrm{R}-$ is reverse scored } \\
\hline \multicolumn{2}{|c|}{ Disagree } & 2 & & & & \\
\hline \multicolumn{2}{|c|}{ No Opinion } & 3 & & & & \\
\hline \multicolumn{2}{|l|}{ Agree } & 4 & & & & \\
\hline \multicolumn{2}{|c|}{ Strongly Agree } & & & & & \\
\hline
\end{tabular}


Table 3: Pearson Correlation Coefficients

\begin{tabular}{|c|c|c|c|c|c|c|c|c|c|c|c|c|c|c|c|c|}
\hline & $\begin{array}{c}\mathrm{I} \\
12\end{array}$ & $\begin{array}{c}\mathrm{I} \\
13\end{array}$ & $\begin{array}{c}\mathrm{I} \\
16\end{array}$ & $\begin{array}{c}\text { I } \\
19\end{array}$ & $\begin{array}{c}\mathrm{I} \\
22\end{array}$ & $\begin{array}{c}\mathrm{I} \\
25\end{array}$ & $\begin{array}{c}\text { I } \\
28\end{array}$ & $\begin{array}{c}\text { I } \\
31\end{array}$ & $\begin{array}{c}\text { I } \\
34\end{array}$ & $\begin{array}{c}\text { I } \\
35\end{array}$ & $\begin{array}{c}\text { I } \\
36\end{array}$ & $\begin{array}{c}\mathrm{I} 43 \\
\mathrm{R}\end{array}$ & $\begin{array}{c}\mathrm{I} 44 \\
\mathrm{R}\end{array}$ & $\begin{array}{c}\mathrm{I} \\
45\end{array}$ & $\begin{array}{c}\text { I } \\
47\end{array}$ & $\begin{array}{c}\text { I } \\
48\end{array}$ \\
\hline $\begin{array}{c}\text { I } \\
12\end{array}$ & 1 & & & & & & & & & & & & & & & \\
\hline $\begin{array}{c}\text { I } \\
13\end{array}$ & $\begin{array}{l}\mathbf{5 0} \\
* *\end{array}$ & 1 & & & & & & & & & & & & & & \\
\hline $\begin{array}{c}\text { I } \\
16\end{array}$ & $\begin{array}{l}.20 \\
* *\end{array}$ & $\begin{array}{l}.25 \\
* *\end{array}$ & 1 & & & & & & & & & & & & & \\
\hline $\begin{array}{c}\text { I } \\
22\end{array}$ & $\begin{array}{l}.24 \\
* *\end{array}$ & $\begin{array}{c}.17 \\
*\end{array}$ & & $\begin{array}{l}.59 \\
* *\end{array}$ & 1 & & & & & & & & & & & \\
\hline $\begin{array}{c}\text { I } \\
25\end{array}$ & & & $\begin{array}{l}.36 \\
* *\end{array}$ & $\begin{array}{c}.18 \\
*\end{array}$ & $\begin{array}{l}.19 \\
* *\end{array}$ & 1 & & & & & & & & & & \\
\hline $\begin{array}{c}\text { I } \\
28\end{array}$ & $\begin{array}{c}.16 \\
*\end{array}$ & & $\begin{array}{l}.28 \\
* *\end{array}$ & & $\begin{array}{l}.23 \\
* *\end{array}$ & $\begin{array}{l}.27 \\
* *\end{array}$ & 1 & & & & & & & & & \\
\hline $\begin{array}{c}\text { I } \\
31\end{array}$ & $\begin{array}{c}.14 \\
*\end{array}$ & $\begin{array}{l}.20 \\
* *\end{array}$ & $\begin{array}{l}.23 \\
* *\end{array}$ & $\begin{array}{l}.36 \\
* *\end{array}$ & $\begin{array}{l}.38 \\
* *\end{array}$ & $\begin{array}{l}.32 \\
* *\end{array}$ & $\begin{array}{l}.42 \\
* *\end{array}$ & 1 & & & & & & & & \\
\hline $\begin{array}{c}\text { I } \\
34\end{array}$ & $\begin{array}{l}.25 \\
* * *\end{array}$ & $\begin{array}{l}.16 \\
*\end{array}$ & $\begin{array}{l}.14 \\
*\end{array}$ & $\begin{array}{l}.42 \\
* *\end{array}$ & $\begin{array}{l}\mathbf{5 2} \\
* *\end{array}$ & $\begin{array}{c}.19 \\
*\end{array}$ & $\begin{array}{l}.36 \\
* * *\end{array}$ & $\begin{array}{l}.48 \\
* *\end{array}$ & 1 & & & & & & & \\
\hline $\begin{array}{c}\text { I } \\
35\end{array}$ & $\begin{array}{c}.15 \\
*\end{array}$ & & & $\begin{array}{l}.27 \\
* *\end{array}$ & $\begin{array}{l}.22 \\
* *\end{array}$ & & $\begin{array}{l}.16 \\
*\end{array}$ & $\begin{array}{l}.32 \\
* *\end{array}$ & $\begin{array}{l}.48 \\
* *\end{array}$ & 1 & & & & & & \\
\hline $\begin{array}{c}\text { I } \\
36\end{array}$ & & & & $\begin{array}{c}.18 \\
*\end{array}$ & & & & $\begin{array}{l}.24 \\
* *\end{array}$ & $\begin{array}{l}.27 \\
* *\end{array}$ & $\begin{array}{l}.73 \\
* *\end{array}$ & 1 & & & & & \\
\hline $\begin{array}{c}\mathrm{I} 44 \\
\mathrm{R}\end{array}$ & & & & & & & & & & & & $\begin{array}{l}.56 \\
* *\end{array}$ & 1 & & & \\
\hline $\begin{array}{c}\mathrm{I} \\
45\end{array}$ & $\begin{array}{l}.19 \\
* *\end{array}$ & $\begin{array}{l}.23 \\
* *\end{array}$ & $\begin{array}{l}.45 \\
* *\end{array}$ & & & $\begin{array}{l}.23 \\
* *\end{array}$ & $\begin{array}{l}.27 \\
* *\end{array}$ & $\begin{array}{l}.26 \\
* *\end{array}$ & $\begin{array}{c}.14 \\
*\end{array}$ & & & $\begin{array}{l}.19 \\
* *\end{array}$ & $\begin{array}{c}.14 \\
*\end{array}$ & 1 & & \\
\hline $\begin{array}{c}\text { I } \\
46\end{array}$ & & & & & & & $\begin{array}{l}.16 \\
*\end{array}$ & & & & & & & & $\begin{array}{l}.19 \\
* *\end{array}$ & \\
\hline $\begin{array}{c}\text { I } \\
47\end{array}$ & & $\begin{array}{l}.22 \\
* *\end{array}$ & $\begin{array}{l}.32 \\
* *\end{array}$ & & & & & $\begin{array}{l}.17 \\
*\end{array}$ & & $\begin{array}{l}.21 \\
* *\end{array}$ & $\begin{array}{l}.16 \\
*\end{array}$ & $\begin{array}{l}.21 \\
* *\end{array}$ & $\begin{array}{l}.27 \\
* *\end{array}$ & $\begin{array}{l}.51 \\
* *\end{array}$ & 1 & \\
\hline $\begin{array}{c}\text { I } \\
48\end{array}$ & & $\begin{array}{l}.19 \\
* *\end{array}$ & $\begin{array}{l}.25 \\
* *\end{array}$ & & & $\begin{array}{c}.15 \\
*\end{array}$ & & & & $\begin{array}{c}.18 \\
*\end{array}$ & & & $\begin{array}{l}.27 \\
* *\end{array}$ & $\begin{array}{l}.43 \\
* *\end{array}$ & $\begin{array}{l}.77 \\
* *\end{array}$ & 1 \\
\hline $\begin{array}{c}\text { I } \\
49\end{array}$ & & & $\begin{array}{l}.19 \\
* *\end{array}$ & & & $\begin{array}{l}.20 \\
* *\end{array}$ & & $\begin{array}{l}.15 \\
*\end{array}$ & & & $\begin{array}{l}.14 \\
*\end{array}$ & $\begin{array}{c}.18 \\
*\end{array}$ & $\begin{array}{l}.39 \\
* *\end{array}$ & $\begin{array}{l}\mathbf{. 3 8} \\
* *\end{array}$ & $\begin{array}{l}.29 \\
* *\end{array}$ & $\begin{array}{c}.16 \\
*\end{array}$ \\
\hline $\begin{array}{c}\mathrm{V} \\
55\end{array}$ & & & & & & & & & & & & & $\begin{array}{l}.16 \\
\left({ }^{*}\right)\end{array}$ & & & \\
\hline
\end{tabular}




\section{Appendix A \\ SOFTWARE COPYING Questionnaire [12]}

For the following items, the authors asked the respondents to circle, based on their beliefs and feelings, the appropriate choice of one of the Likert scale choices as given below:

$\begin{array}{lllll}\text { Strongly Disagree Disagree No opinion } & \text { Agree } & \text { Strongly Agree } \\ 1 & 2 & 3 & 4 & 5\end{array}$

I12. I believe most people copy commercial software instead of buying it.

I13. I believe most students copy commercial software instead of buying it.

I16. I think it is alright for a student to copy commercial software instead of buying it.

I19. I think is alright for $a$ student to use university computers and software for nonuniversity activities.

I22. I think it is alright for a student to use university computers and software for their social organizations.

I25. I think it is all right for a student to copy commercial software to evaluate it for possible purchase.

I28. I think it is alright for a student to use a university owned software at home to complete university assignments.

I31. I think it is alright for a student to use a university owned software at home for personal use.

I34. I think it is alright for a student to use university computer and software for their benefits as long as it has no adverse effect on others.

I35. I think it is alright for a student to use university computer and software for their benefits as long as it has only minor adverse effect on others.

I36. I think it is alright for a student to use university computer and software for their benefits regardless of its effect on others.

I43. I think it is illegal for a student to copy commercial software instead of buying it.

I44. I think it is illegal for anybody to copy commercial software instead of buying it.

I45. I think it alright for me to use copied software if I would not buy it in any case.

I46. I think it is alright for me to "try out" software so long as I intend to buy it in the future.

I47. I think it is alright for me to copy commercial software if most people do it.

I48. I think it is alright for me to copy commercial software because it is unlikely that I will be caught.

I49. I do not think it is right to copy commercial software.

V55. I think for every 100 legal copies of software in the market there are at least illegal copies made of the same software in the U.S. 


\section{Appendix B}

\section{Kohlberg's levels of Moral Development [12][13]}

Level 1- Preconventional Level: Individuals begin their moral development with an internal focus, first to avoid punishment then to achieve some level of selfgratification.

Stage 1 - Action is motivated by avoidance of punishment and "conscience" is irrational fear of punishment.

Stage 2 - Action is motivated by desire for reward or benefit. Possible guilt reactions are ignored and punishment viewed in a pragmatic manner. (Differentiates own fear, pleasure, or pain from punishment-consequences.)

Level 2 - Conventional Level: At this point in the development process individuals focus more on a group. This is the level at which peer pressure begins to exert its influence. An individual who develops beyond the stage of peer pressure will begin to look at rules as defining behavior.

Stage 3 - Action motivated by anticipation of disapproval of others, actual or imagined - hypothetical. (e.g., guilt).

Stage 4 - Action motivated by anticipation of dishonor, i.e., institutional blame for failure of duty, and by guilt over concrete harm done to others.

Level 3 - Postconventional level: This is the point at which individuals are more concerned with ramifications toward society in general.

Stage 5 - Concern about maintaining respect of equals and of the community. Stage 6 - Concern about self-condemnation for violating one's own principles.

Items relevant to Kohlberg's Stages

Stage 2: I12, I13, I36, I48

Stage 3: I16, I19, I22, I45, I47

Stage 4: I25, I28, I31, I35, I43, I44, I46

Stage 5: I34

Stage 6: I49 